\title{
PSYCHOLOGICAL AND SOCIAL DETERMINANTS OF EARLY MARRIAGE IN WONOGIRI, CENTRAL JAVA
}

\author{
Mirna Prawita' ${ }^{1}$, RB Soemanto's), Bhisma Murti' ${ }^{1)}$ \\ ${ }^{1)}$ Masters Program in Public Health, Universitas Sebelas Maret \\ 2)Faculty of Social and Political Sciences, Universitas Sebelas Maret
}

\begin{abstract}
Background: Child marriage disproportionately affects girls and has an impact on their mental and physical health for the rest of their lives. Not only are they denied the right to choose their own partner, they are marginalized and subject to various religious, societal, political, and cultural practices that fail to honor their basic human rights. This study aimed to examine psychological and social determinants of early marriage in Wonogiri, Central Java.

Subjects and Method: A case control study was conducted at 25 villages in Wonogiri, East Java, in December 2018. A sample of 225 women was selected by fixed disease sampling. The dependent variable was early marriage. The independent variables were intention, attitude, perceived behavior control, paternal education, maternal education, and information exposure. The data were collected by questionnaire and analyzed by path analysis.

Results: Early marriage directly increased with strong intention $(b=1.74 ; 95 \% \mathrm{CI}=0.9$ to $2.45 ; \mathrm{p}<0.001)$, negative attitude $(\mathrm{b}=1.92 ; 95 \% \mathrm{CI}=1.17$ to $2.67 ; \mathrm{p}<0.001)$, but decreased with strong perceived behavior control $(b=-0.92 ; 95 \% \mathrm{CI}=-1.55$ to $-0.18 ; \mathrm{p}=$ o.013). Early marriage was indirectly affected by paternal education, maternal education, knowledge, education, family income, gender equality, social norm, and subjective norm.

Conclusion: Early marriage directly increases with strong intention, negative attitude, but decreases with strong perceived behavior control. Early marriage is indirectly affected by paternal education, maternal education, knowledge, education, family income, gender equality, social norm, and subjective norm.
\end{abstract}

Keywords: Early marriage, gender equality, social norm, intention

\section{Correspondence:}

Mirna Prawita. Masters Program in Public Health, Universitas Sebelas Maret, Jl. Ir. Sutami 36A, Surakarta 57126, Central Java, Indonesia.

Email: mirna.prawita2013@gmail.com. Mobile: 085642331691

The $5^{\text {th }}$ International Conference on Public Health 